\title{
The Determinants of Corporate Social Responsibility Disclosure: Empirical Evidence from Indonesia Listed Firms
}

\author{
Sofik Handoyo \\ Faculty of Economics and Business \\ Universitas Padjadjaran
}

\begin{abstract}
The study was motivated by previous research findings that indicate the variations of corporate social responsibilities disclosure among countries. The purpose of the study is to examine the determinants that influence corporate social responsibilities disclosure. The determinants namely the firm size, firm age, earning per share, stock price, and industry type, were examined. The sample of the study is listed firms in Indonesia Stock Exchange that issued sustainability reporting. Content analysis of sustainability reporting using the global reporting initiative standard was conducted to measure corporate social responsibilities disclosure. The determinants were examined using multiple regression analysis with confidence interval level of $95 \%$. The results indicated that the firm size, earning per share and stock price significantly influence the corporate social responsibilities disclosure. Empirical findings of the study contribute in terms of giving an understanding of practice corporate social responsibilities disclosure in a developing country, especially in Southeast Asia region. Furthermore, the findings provide valuable information for conducting cross countries comparative studies.
\end{abstract}

Keywords: Corporate Social Responsibility Disclosure; Earning Per Share; Firm size; Firm age; Industry type; Stock price

\section{Introduction}

In line with increasing awareness of stakeholders toward social and environmental issues, Corporate Social Responsibilities Disclosure (CSRD) has been gaining popularity among business entities, academics, and practitioners (Djajadikerta \& Trireksani, 2012; Hooks \& van Staden, 2011). CSRD is an integral part of the firm's annual report that complements financial information. Impact of industrialization raises the concern of stakeholders toward sustainability issues. It affects stakeholders in terms of consumer behavior, government's law enforcement, investment decision, and social movement. Assessing the firm performance, stakeholders no longer rely on financial information only but also non-financial information such as CSR information. CSRD becomes a strategic tool for the business organization for building company image and improving the firm value (Wang, Yu, \& Ahsan, 2016). Since then, the role of CSRD for the firms is pivotal and goes beyond supplementary information only.

CSRD has been studied by many scholars around the world, however, most of them were conducted in the context of western developed countries (Hooks \& van Staden, 2011). There is a lack of CSED studies done in Asia region especially in developing countries (Belal \& Momin, 2009; Djajadikerta \& Trireksani, 2012). In the Asian context, most of the CSED studies have been conducted in developed or newly developed countries (Ahmad \& Sulaiman, 2004). Especially in Southeast Asia, there is still an urgency to understand the practice of CSRD in this region. Previous studies indicated there are variations among countries and individual firm in terms of its CSRD performance (Chapple \& Moon, 
2005; Sethi, Martell, \& Demir, 2017). Furthermore, findings related to CSRD studies tend to inconclusive (Herbohn, Walker, \& Loo, 2014). In Indonesia context, based on a study conducted by Gunawan, Djajadikerta, and Smith (2009) indicated that the overall quality of CSRD among listed firms is poor. However, some listed firms showed excellent performance of CSRD. It implies that firms behave differently regarding its CSRD. Therefore, the study to understand the determinants of CSRD performance is relevant to be conducted.

In general, the study gives a contribution in terms of understanding the practice of CSRD in the South East Asian region especially for the case of a developing country such as Indonesia. Specifically, studying the determinants of CSRD enriches the body of knowledge in answering the phenomena of CSRD performance variation among listed firms. Especially for Indonesia, the finding of this study adds information for discourse analysis toward inconsistency results of previous studies conducted in Indonesia. Majority literature supported the premise that CSRD closely associated with country characteristics (Chapple \& Moon, 2005; Djajadikerta \& Trireksani, 2012). Companies which operate in a particular country face an economic and cultural environment, moral judgment, political systems, and civil systems, specific to that country (Djajadikerta \& Trireksani, 2012). The finding of this study provides valuable information for CSRD cross countries comparative studies, especially the study that involve the country characteristics such as public governance and cultural aspect.

The literature provides a wide range of perspective in the understanding of the determinants of CSRD. However, characteristics of the firms are the factor found frequently in the literature as a proxy of CSRD performance (Lu \& Abeysekera, 2014), and it refers to firm size, firm age, and industry type. Firm size becomes determinant of CSRD disclosure due to media publication tend to give more attention to large scale firms that audience already familiar rather than unknown small firms (Reverte, 2009; Waluyo, 2017). The large firms anticipate the risk of bad news media publication through well informed CSRD. Firm age as the determinant of CSRD is based on the premise that firms on the mature stage have experience more in dealing with any circumstances that affect the sustainability of the firms (Gantyowati \& Agustine, 2017). Due to its experience, mature firms have a reputation and history relationship with stakeholders that leads to its CSRD performance (Withisuphakorn \& Jiraporn, 2016; Wuttichindanon, 2017).

Types of the industry in the perspective of CSRD studies are classified into Environmental sensitive Industry (ESI) and Non-Environmental Sensitive Industry (NESI)(Liu \& Anbumozhi, 2009). NESI is the target of media exposure and government regulation compliance; therefore, they tend to disclose more CSR information compared to ESI (Liu \& Anbumozhi, 2009; Reverte, 2009). Besides the firm characteristics, financial aspects of the firm such as Earning Per Share (EPS) and stock price are considered as the determinants of CSRD. The firms with higher EPS and stock price tend to avoid asymmetry information for investors (Ji, Xu, \& Zhao, 2019; Kaskeen, 2017; Xu \& Liu, 2018). Fully and publicly disclose information in CSR reporting is one the mechanism to reduce asymmetry information.

The study was inspired by the phenomena of variations of CSRD among countries and individual firms. The characteristic of the firm and financial aspects of the firms are considered as determinants of CSRD. The main purpose of this study is to examine the influence of determinants namely the firm size, firm age, earning per share, stock price and industry type on CSRD performance of Indonesian listed firms

\section{Method}

The population in this study is all listed firms in Indonesia Stock Exchange. The sample was chosen using purposive sampling technique. Listed firms that issued sustainability reporting along with its annual report were criteria used for choosing sample firms. Description of the sample firms is depicted in Table 1 . The period of investigation in this study is the year 2017. 
Table 1. Sample Distribution

\begin{tabular}{lcc}
\hline \multicolumn{1}{c}{ Industry Sector } & Sample Size & $\begin{array}{c}\text { Percentage of } \\
\text { Total Sample }\end{array}$ \\
\hline Agriculture & 5 & $14 \%$ \\
Mining & 5 & $14 \%$ \\
Basic Industry and Chemical & 5 & $14 \%$ \\
Consumer Goods & 2 & $6 \%$ \\
Finance & 5 & $14 \%$ \\
Infrastructure, Utilities and Transportation & 5 & $14 \%$ \\
Miscellaneous Industry & 1 & $3 \%$ \\
Property, Real Estate, \& Building Construction & 4 & $11 \%$ \\
Trade, Services, \& Investment & 4 & $11 \%$ \\
\hline Total & $\mathbf{3 3}$ & $\mathbf{1 0 0 \%}$ \\
\hline
\end{tabular}

Multiple linear regression analysis was applied in this study. The dependent variable in this study is the Corporate Social Responsibility Disclosure (CSRD). Meanwhile, firm size, firm age, Earning Per Share (EPS), stock price, and industry type were treated as an independent variable. The model of the multiple linear regression equation was formulated as follows:

$\mathrm{CSRD}_{\mathrm{it}}=\beta_{1}$ Size $_{\mathrm{it}}+\beta_{2} \mathrm{Age}_{\mathrm{it}}+\beta_{3} \mathrm{EPS}_{\mathrm{it}}+\beta_{4} \mathrm{SP}_{\mathrm{it}}+$ $\beta_{5} \mathrm{IT}_{\mathrm{it}}+\varepsilon_{\mathrm{it}}$

Where CSRD is the Corporate Social Responsibility Disclosure, $\mathrm{i}$ is the variables, $\mathrm{t}$ is the period of variables, size is the firm size, age is firm age, EPS is earning per share, SP is stock price, IT is industry type, and $\varepsilon$ is an error. The data was collected from a sustainability report, annual report and stock price database of Indonesia Stock Exchange (IDX). The significant level was used to analyze whether the model is supported or rejected is Alpha $(\alpha)$ 0.05 . SPSS software version 23 was used to process the data. Content analysis of the sustainability report was conducted in order to obtain a CSRD score. Information in the sustainability report was confirmed with the Global Reporting Initiative (GRI) guideline of version 4.0, which is standard reporting for Corporate Social Responsibility (CSR) widely used in practice. There are three aspects of CSR regulated in GRI namely economic, social and environment. It consists of 13 items information of economic aspect, 30 items information of environmental aspect and 34 items information of social aspect. Therefore, in total there are 77 CSR information items were identified in this study. The score of CSRD was calculated using the following formula:

$$
\operatorname{CSRD}_{j}=\sum_{t=1}^{n j} \frac{X i j}{n j}
$$

Where,

$\mathrm{CSRD}_{\mathrm{j}}=$ Corporate Social Responsibility

Disclosure score for $j^{\text {th }}$ firm

$\mathrm{nj} \quad=$ Total number of items for $\mathrm{j}^{\text {th }}$ firm if the items fully disclosed

$\mathrm{Xij}=$ Number of items disclosed for $\mathrm{j}^{\text {th }}$ firm (Point 1 (one) was given if the item disclosed and point 0 (zero) for not disclosing)

The total asset of the firms and the length time of the firm established are indicators to measure the firm size and firm age. Both information was collected from the firm's annual report. In order to avoid multicollinear and problem of normal distribution data, raw data of total assets, and length time of the firm established were transformed into logarithmic natural (Ln). Meanwhile, the ratio of net income to outstanding stock was used as a proxy for measuring EPS. Stock price in this study referred to the price of a stock in Indonesia Capital market when CSR report released. Industry type in this study refers to industry classification namely environmental sensitive industry (ESI) and non-environmental sensitive industry (NESI). Industry type was treated as a dummy variable. Sample firms in the categorization of ESI were given an identification value of 2 (two) and 1 (one) for NESI. Summary of measurement each variable is presented in Table 2. 
Table 2. Variable and Measurement

\begin{tabular}{|c|c|c|}
\hline Variable & Dimension & Indicator \\
\hline $\begin{array}{l}\text { Corporate Social } \\
\text { Responsibility } \\
\text { Disclosure (CSRD) }\end{array}$ & $\begin{array}{l}\text { Corporate Social Responsibility items of } \\
\text { information based on GRI guidelines }\end{array}$ & CSRD score \\
\hline Firm Size & Size of the total asset of the firm & Ln (Firm total assets) \\
\hline Firm Age & Length time of the firm established & $\begin{array}{l}\text { Ln (Length time of the firm } \\
\text { established) }\end{array}$ \\
\hline $\begin{array}{l}\text { Earnings Per Share } \\
\text { (EPS) }\end{array}$ & $\begin{array}{l}\text { A portion of a firm profit allocated to } \\
\text { shareholders }\end{array}$ & $\begin{array}{l}\text { A ratio of net income to } \\
\text { Outstanding Stocks }\end{array}$ \\
\hline Stock Price & Price of stock in the capital market & $\begin{array}{l}\text { The stock price at the released } \\
\text { date of the CSR report }\end{array}$ \\
\hline Industry Type & $\begin{array}{l}\text { Classification of industry into Environmental } \\
\text { Sensitive (ESI) and Non-Environmental } \\
\text { Sensitive (NESI) }\end{array}$ & $\begin{array}{l}\text { Dummy Variable, ESI }=2, \\
\text { NESI }=1\end{array}$ \\
\hline
\end{tabular}

\section{Results and Discussion}

The study was designed to examine the determinants that influence CSRD. The determinants in this study refer to the firm size, firm age, earning per share, stock price and industry type. The first hypothesis examined the relationship between firm size and CSRD. Firm size refers to the scale of the firm which is in general associated with total assets. Theory suggests that the scale of the firm will determine the scope of the social responsibilities. Due to its massive business operation, large scale firms are associated with high-intensity interaction with the stakeholders (employee, society, government, shareholders, creditors, etc). It is, therefore, firm activities that are dealing with stakeholders would be more intensive compared with small scale firms. Furthermore, large scale firms are the target of high exposure of media and the center of attention of stakeholders (Reverte, 2009; Waluyo, 2017). This study predicted that the firm size influences the CSRD. Regression analysis (Table 3 ) indicated that the firm size is significant to explain the variance of CSRD ( $\beta$ $=-0.461, \mathrm{p}<0.05)$. Therefore, hypothesis 1 (one) that stated the firm size is a function of CSRD score is supported.

Table 3. Regression Analysis Result

\begin{tabular}{lccc}
\hline Variable & $\begin{array}{c}\text { Standardized } \\
\text { Coefficient }(\boldsymbol{\beta})\end{array}$ & Sig \\
\hline Firm Size & $-0.461^{*}$ & -2.961 & 0.006 \\
\hline Firm Age & 0.163 & 1.109 & 0.276 \\
\hline EPS & $0.770^{*}$ & 3.377 & 0.002 \\
\hline Stock Price & $-0.606^{*}$ & -2.715 & 0.011 \\
\hline Industry Type & 0.140 & 0.916 & 0.367 \\
\hline F & $4.510^{*}$ & & 0.003 \\
\hline R Square & 0.429 & & \\
\hline Adjusted R Square & 0.334 & & \\
\hline * $<0.05$ & & & \\
\hline
\end{tabular}


In Indonesia context, the finding is consistent with the previous studies conducted by Irham, Yuliana, and Widiyanti (2018), Gantyowati and Agustine (2017), and Waluyo, (2017). In Asia context, the finding of the study also supports previous studies conducted in Bahrain, Jordan, Taiwan, India, Saudi Arabia, Thailand and China (Ali Al-Gamrh \& Ahmed AL-Dhamari, 2016; Bani-Khalid, Kouhy, \& Hassan, 2017; Juhmani, 2014; Kansal, Joshi, \& Batra, 2014; Wuttichindanon, 2017). Research conducted in Europe by Reverte (2009) who studied CSRD in Spain found that the firm size positively associated with CSRD. Dias, Rodrigues, Craig, \& Neves ( 2019) who studied CSRD in Portugal found a similar finding with the previous study by Reverte (2009) that larger companies disclose more information on environment and society. Even though the majority of studies found that the firm size is positively associated with CSRD, however, the results are still inconclusive. The study by Swandari \& Sadikin (2016) and Sethi, Martell, and Demir (2017) found that the firm size has no influence on CSRD performance.

There is concern related to the result of this study. Based on regression analysis results presented in Table 3, the influence of a firm size showed a negative direction $(\beta=-0.461)$. The result implies that bigger firm size tends to have lower CSRD and vice versa. Previous studies conducted by Nawaiseh, Boa, Zaid, \& ElShohnah ( 2015) and Holder-Webb, Cohen, Nath, and Wood (2009) also found a negative association between firm size and CSRD. The negative influence of firm size and CSRD indicating anomaly result. There are some argumentations that explain the phenomena of a negative association between firm size and CSRD. Nawaiseh et al. (2015) argued that cost and benefits consideration might influence the bigger firm scale presenting poor CSRD compared to small scale firms. Large scale firms, in general, have sufficient resources, including financial resources to support business operation. Less dependency on stakeholders makes large firms consider that CSRD is not necessary to do. Holder-Webb et al. (2009) argued that CSRD is a manifestation of informal unobservable channels of communication between firms and stakeholders. To growth, small firms have concern presenting good or excellent CSRD in order to create a good image and reputation.
Therefore, on the perspective small firms, CSRD is a strategy to get the impression from stakeholders. The practice of CSRD in Indonesia is not yet supported by proper rules and regulations. Indonesia's corporation law obliges companies to report their social and environmental activities in their annual reports. Unfortunately, there is no regulation following up this obligation in terms of the details and technical of CSRD (Utama, 2011) and it may explain why the practice of CSRD in Indonesia is relatively poor.

The second hypothesis tested the relationship between firm age and CSRD performance. The firm age is defined as the time of recording from the beginning establishment until now or from the merger made by the firm (Loderer \& Waelchli, 2010). The theoretical framework assumes that more mature firms will invest more in CSR (Withisuphakorn \& Jiraporn, 2016). When a corporation matures, its reputation and history of involvement in social responsibility become entrenched (Wuttichindanon, 2017). It is believed that the firms will become more experience in line with the length of time firm's existence (Gantyowati \& Agustine, 2017). The longer time the company operates, there will be more interaction with the outside community for building a public image. An older company will involve more social responsibility than the younger company (Deegan, 2002). A matured firm is a firm whose products are well known and have loyal customers. By having loyal customers, the matured firm will get more attention from the public and therefore need to maintain its reputation (Deegan, 2002). The growing maturity of the firm, the obligation to make environmental disclosures to meet the expectations of the community and stakeholders, becomes increasingly high.

Regression analysis (Table 3) showed that the result is insignificant $(\beta=0.146, p$ > $0.05)$. The result implies that a firm size had no significant evidence to explain the CSRD performance variance. It can be concluded that the maturity of the firms will not make different in terms of its CSRD performance. Therefore, hypothesis 2 (two) that proposed that the firm age influenced CSRD is not supported. Previous studies conducted by Bani-Khalid et al. (2017) and Wuttichindanon (2017) indicated the negative effect of firm size and CSRD 
performance. Withisuphakorn and Jiraporn (2016) who studied the effect of firm maturity on CSRD concluded that the effect of firm maturity is not uniform across different categories of CSRD. Noordin and Mohtar (2014) argued that firm age might behave differently according to the types of firms. It implies that the firm age may influence CSRD in a certain type of firms and can not be applied to all types of firms.

Authors believe that the firm age didn't have any role in CSRD when rules and regulation enforced properly. Mature firms and young firms will be treated equally regarding CSRD on behalf of the legal system. In Indonesia perspective, CSRD is not highly regulated in terms of content and format of reporting. Therefore, there is a tendency that CSRD among Indonesia listed firms vary in terms of the way it is reported and therefore, the quality of the content presented in the CSRD is relatively poor (Narullia, Subekti, Azizah, \& Purnamasari, 2019). In order to improve the quality of CSR reporting, Madugba and Okafor (2016) suggested that the government should play its role through rules and regulations instrument. Alsaeed (2006) argued that the firms only concern to issues that have a direct impact on business operation. So that even though the company has large total assets, these assets will not be used in the area of CSR programs but more significantly to finance other aspects that have a direct impact on firms operation. Furthermore, the firm in Indonesia may consider CSR information is secondary information that is not strategically being the priority. Therefore, even big scale firms have no interest to make full disclosure of CSR information.

It seems that there is a polarization of research findings that investigated the relationship between firm age and CSRD performance. There are several previous studies that supported the premise that the firm maturity positively influenced the CSRD performance. Studies conducted by Ali AlGamrh and Ahmed AL-Dhamari (2016), Waluyo (2017) and Withisuphakorn and Jiraporn (2016) found that firm age is a function of CSRD performance. Based on the perspective of Indonesia, empirical finding in this research is inconsistent with the previous study conducted by Waluyo (2017) who studied the effect of firm size on CRD of real estates companies in Indonesia. A study by Waluyo (2017) focused on a specific type of firm, which is real estate. Meanwhile, in this study involved multiples type of firms. Each type of firms may behave differently regarding the practice of CSRD. There is a certain type of firms where the maturity of the firm plays a significant role in terms of how CSR information disclosed. On the other hand, there is a condition where the maturity of the firm does not play any role in CSRD. Therefore, future research should consider treating the type of firms as control variable instead of an independent variable.

The third hypothesis examined the relationship between Earning Per Share (EPS) with CSRD performance. EPS refers to the portion of a company's profit allocated to each outstanding share of common stock (Madugba \& Okafor, 2016; Santhirasegar, Ramakrishnan, Hishan, \& Jamal, 2018). Kaskeen (2017) argued that corporate social responsibilities increase in line with increasing the level of EPS. Earnings information is still the most relevant financial information for measuring the company's value (Narullia et al., 2019). Financial factors including EPS, influence the quality of corporate social responsibility (Ortas et al., 2017). In the previous studies, EPS was treated mostly as part of the outcome of CSRD practice. In this study, the authors did not agree with the concept of CSRD influencing EPS. Authors think otherwise, EPS should determine the CSRD performance among the firms. CSRD in nature is just information regarding activities already conducted by the firms consisting of social, economic and environmental information. Unlike product quality, competitive price and cost efficiency that can influence directly to the financial performance of the firms, EPS should be treated as the determinant of CSRD performance.

Regression analysis presented in Table 3 indicated that EPS is positively significantly explaining the variance of CSRD performance among sample firms $(\beta=0.770, p<0.05)$. It means that the firms that have higher EPS tend to have a better performance of CSRD. Therefore, hypothesis 3 proposed in this research is supported. The finding is consistent with previous research conducted in Indonesia by Citraningrum, Handayani, and Nuzula (2014), Fauzan and Kuswanto (2018), and 
Prasojo \& Listyorini (2015). Even though the majority of studies conducted in Indonesia found that EPS and CSRD performance positively significantly associated, however, the results are still inconclusive. One study conducted in Indonesia by Kamatra and Kartikaningdyah (2015) found that EPS is not significant in explaining the variance of CSRD performance. The study that reveals the association between EPS and CSRD performance seems to indicate mixed results. Gantyowati and Agustine (2017) who made a comparative study between Indonesia and Malaysia revealed that there are inconsistent results. They found that liquidity in Indonesian firms, including EPS, show a positive effect on CSRD performance, while in Malaysia, it shows a negative effect on CSRD performance. A research finding by Fauziah and Adamu (2016) who studied the relationship between CSRD and EPS in Malaysia affirmed the statement that there are mixed results regarding those two variables.

In the international level, the study that investigated the relationship between EPS and CSRD performance was also found inconsistent results. The study by Bagh, Khan, Azad and Atif Khan (2017), Pan, Sha, Zhang, and Ke (2014), and Shoukat Malik \& Nadeem (2014) indicated that there is a positive and significant association between EPS and CSRD performance. However, studies conducted Madugba and Okafor (2016), Santhirasegar et al. (2018), and Kaskeen (2017) indicated that EPS did not play a role in CSRD performance. Ali and Rizwan (2013) argued that CSR reporting is more heavily influenced by the external forces stakeholders rather than the factor from the internal organization (Ali \& Rizwan, 2013). Government is one of the examples of external stakeholder that has a powerful influence to force the firms through rules and regulation instrument. NonGovernmental Organizations (NGOs) that concern on social and environmental issues is another example of external stakeholder forces play a key role in how CSRD practiced by the firms. Effective government through law enforcement and watchdog function of NGOs may affect the performance of CSRD among firms in a certain country through check and balance mechanism.

The fourth hypothesis examined the relationship between stock price and CSRD performance. Using stakeholders theory perspective, one of the responsibilities of the firms is to maximize shareholders value (Fiori, Di Donato, \& Izzo, 2015). The performance of the shareholder value can be identified from its stock price. The stock price is not only associated with financial performance but also social performance. It is, therefore, CSR information is no longer considered as secondary information but a strategic tool to improve shareholders value. The firms with a higher stock price were predicted to have higher social responsibility compared to firms with a lower stock price. Ji, Xu, and Zhao (2019) argued that CSRD is closely associated with stock liquidity and stock price. Stock price volatility and liquidity are proxies for CSR disclosure in reducing stock market information asymmetry (Xu \& Liu, 2018). It is, therefore, in this study stock price was treated as a function of CSRD performance. Hypothesis 4 predicted that the stock price of the firm influences the CSRD performance.

Regression analysis presented in Table 3 shows that stock price significantly explains the variance of CSRD performance among sample firms $(\beta=-0.606, p<0.05)$. Therefore, statement of hypothesis 4 is supported. However, there is concern related to the result of the study, which is $\beta$ indicated negative sign $(\beta=-0.009)$. It means that the firms with higher stock price tend to have a lower performance of CSRD. Even though the hypothesis is supported, however, the result is not as expected in terms of the direction of the influence, which is expecting a positive influence. In Indonesia perspective, a study by Nurcahyanti and Widhianningrum (2018) found that there is no relationship between stock price and aggregate CSRD performance. Stock price and CSRD performance are closely associated in terms of environmental aspect only. Zaccheaus, Oluwagbemiga, and Olugbenga (2014) argued that the firms tend to comply with law and ethics, building favorable business atmosphere, and a good marketing strategy. Environmental aspect in nature is much more related law and regulations compliance, while social aspects are closely associated with philanthropy. The negative influence of stock price on CSRD is consistent with previous researches conducted by Wang (2017), Fiori et al. (2015), Izzo and di Donato (2012), Izzo and di Donato (2012), Zaccheaus et al. (2014). Dasgupta, Laplante, \& 
Mamingi (1998) argued that one of the reason stock prices not related to CSRD is capital market maturity. In nature, the Indonesia capital market is classified as inefficient, because the investor did not absorb available information for an investment decision (Dasgupta et al., 1998). Investor in Indonesia tends to use primary information such as financial reporting rather than non-financial reporting such CSRD. Since investors are not relying on investment decision based on CSR information, firms consider the CSRD is less relevance. It may explain why in this research stock price negatively associated with CSRD performance.

The study that reveals the association between stock price and CSRD is inconclusive. Despite the results that indicated a negative association between stock price and CSRD performance, numerous studies found contrary. Studies conducted by Müller and Wikström (2016), Park and Lee, (2018), and Klerk Villiers and Staden (2015) found a positive and significant association between stock price and CSRD performance. Kim, Li, and $\mathrm{Li}$ (2014) argued that stock price as a function of CSRD performance is particularly important when governance mechanisms, such as monitoring by boards or institutional investors, are weak. Firms with high stock price have the initiative to disclose CSR information better due to investors consider CSR information is important for assessing the risk of stock prices (Khajavai, Taghizadeh, \& Maharluie, 2016). However not all CSR information is treated as important information for investment decision by investors. A study conducted by Müller \& Wikström (2016) indicated that CSR disclosure related to philanthropic (social aspects) had no association with the stock price. CSR activities that have a strong correlation with stock price is environmental CSR activities (Müller \& Wikström, 2016). Flammer (2013) argued that CSR depends on external and internal moderators and it is believed that stock price is acting as external moderators

Hypothesis 5 examined the influence of industry type and CSRD performance. Industry types in this study refer to the classification of the industry into categorization namely an Environmentally Sensitive Industry (ESI) and Non-Environmentally Sensitive Industry (NESI). ESI was predicted to disclose more CSR information compared to NESI. In nature, the business operation of ESI is dealing a lot with issues such as quality of environment and impact of industrialization on public health. Therefore, the intensity of CSR activities conducted by ESI is higher if it is compared with NESI. Using perspective legitimation theory, ESI needs to disclose more CSR information in order to obtain legitimization of business operation from the stakeholders. Reverte (2009) argued that ESI in nature gets more media exposure than NESI. Therefore, ESI anticipated media critics and bad news released by disclosing more information on CSR reporting. ESI is highly regulated by authorities, therefore pressure from the government make ESI tend to disclose CSR information more intense compared to nonNESI (Liu \& Anbumozhi, 2009)

Regression analysis depicted in Table 3 indicated that industry type and CSRD is positively associated. However, industry type is insignificant to explain the variance of CSRD performance among sample firms $(\beta=0.140$, p>0.05). It implies that between ESI and NESI do not have significant differences in terms of the way CSRD presented. ESI indeed tends to disclose more CSR information with the indication of coefficient regression $\beta=0.140$. However, the degree of the influence of industry type is not convincing. Therefore, hypothesis 5 that stated industry types influence CSRD is not supported. Finding in this study is consistent with the previous study conducted by Djajadikerta and Trireksani (2012) who studied CSRD in Indonesia. They argued that the practice of CSRD in Indonesia is still at an early stage. The firms conducting CSRD is merely expecting to gain societal recognition of the adequacy of their social behavior rather than a form of responsibility to stakeholders (Djajadikerta \& Trireksani, 2012). Based on the authors perspective, law enforcement in Indonesia related compliance of environmental and societal issues is not working properly. The authority is relatively soft in responding to any violation of rules and regulations related to CSR did by the business organizations. It is, therefore, the business organization in Indonesia whether ESI or NESI category both showed indifference behavior regarding CSRD practice.

There are inconsistent results of studies regarding the relationship between industry 
types and CSRD performance. However, the majority of the studies found that there is a significant influence of industry types on CSRD (Reverte, 2009). The inconsistency results may be caused by country-specific factors (Djajadikerta \& Trireksani, 2012). Sethi et al. (2017) found that legal factors and CSR environment in a firm country of headquarters play an important role in firms' CSR reporting quality. Therefore, forthcoming researches are suggested to include country-specific variable such as public governance as control variables. Comparative studies between developed countries and developing countries are also relevant to be conducted in the future to understand the role of the country economy in CSRD practice. In order to get a clear understanding of the determinants of CSRD, it is still a long way to go. Therefore, a new approach of research, the object of the studies, the sample of the research, involving more complex variables are encouraged to be conducted in the future. The summary of the posited hypotheses and its conclusion is presented in Table 4.

Table 4. Summary of hypothesis testing

\begin{tabular}{lccl}
\hline \multicolumn{1}{c}{ Hypothesis } & $\begin{array}{c}\text { Significant } \\
\text { Level }(\boldsymbol{\alpha})\end{array}$ & p-Value & Conclusion \\
\hline Firm Size $\rightarrow$ CSRD Performance & 0.05 & 0.006 & Significant \\
\hline Firm Age $\rightarrow$ CSRD Performance & 0.05 & 0.276 & Insignificant \\
\hline EPS $\rightarrow$ CSRD Performance & 0.05 & 0.002 & Significant \\
\hline Stock Price $\rightarrow$ CSRD Performance & 0.05 & 0.011 & Significant \\
\hline Industry Type $\rightarrow$ CSRD Performance & 0.05 & 0.367 & Insignificant \\
\hline
\end{tabular}

The research proposed a model that variables, namely the firm size, firm age, EPS, stock price and industry type are a function of CSRD performance. Summary of multivariate regression analysis presented in Table 3 indicates that the model is fit and significant to explain the variance of CSRD $(F=4.510$, $\mathrm{p}<0.05)$. It means that the firm size, firm age, EPS and stock price simultaneously are determinants of CSRD performance. The testing model revealed R-Square of 0.429 which is significant at the 0.05 alpha level. It implies that the firm size, firm age, EPS, stock price and industry types simultaneously influence of $42,9 \%$ on CSRD performance.
The remaining $(57,1 \%)$ is influenced by other variables that are not investigated in this study. The individual contribution of each determinant is presented in Table 5. Based on information in Table 5, firm size, firm age, EPS, stock price and industry types contributed to CSRD of $15,6 \%, 3,2 \%, 14,6 \%, 4,6 \%$ and $4,8 \%$ respectively. Firm size and EPS are the determinants that contributed to CSRD performance the most. It implies that the scale of the firm and financial performance (EPS) are convincing determinants to predict the behavior of the firm in terms of presenting CSR information.

Table 5. Partial Coefficient of Determination

\begin{tabular}{lccc}
\hline Model & $\begin{array}{c}\text { Standardized } \\
\text { Coefficients }\end{array}$ & $\begin{array}{c}\text { Correlations } \\
\text { Zero-order }\end{array}$ & $\begin{array}{c}\text { Partial Coefficient of } \\
\text { Determination }\end{array}$ \\
\hline Firm Size & $-0,461$ & $-0,339$ & $15,6 \%$ \\
Firm Age & 0,163 & 0,199 & $3,2 \%$ \\
EPS & 0,770 & 0,189 & $14,6 \%$ \\
Stock Price & $-0,606$ & $-0,077$ & $4,6 \%$ \\
Industry Type & 0,140 & 0,345 & $4,8 \%$ \\
\hline \multicolumn{4}{c}{} \\
\hline
\end{tabular}




\section{Conclusion}

The study was intended to reveal the determinants that influence CSRD performance. The model of study proposed 4 determinants as a function of CSRD performance namely the firm size, firm age, EPS and stock price, and industry type. The results indicated that the firm size, EPS and stock price were found significantly influenced the CSRD performance. Meanwhile, the firm age and industry type were found insignificant to explain the variance of CSRD performance. The empirical finding found that firm size and EPS are two dominant factors that influence CSRD performance. The stock price even though found significant to explain the variance of CSRD performance, however, the degree of influence intensity relatively weak compared to the firm size and EPS. Firm age and industry types in this study are empirically failed to prove to have a contribution to CSRD performance. Country-specific factors such as public governance (voice and accountability, political stability, government effectiveness, regulatory quality, the rule of law, control of corruption) are predicted to have a role in CSRD practice. Therefore, including countryspecific factors as a control variable for future similar studies are suggested.

\section{References}

Ahmad, N. N. N., \& Sulaiman, M. (2004). Environment disclosure in Malaysia annual reports: A legitimacy theory perspective. International Journal of Commerce and Management, 14(1), 44-58. https://doi.org/10.1108/10569210480000173

Ali Al-Gamrh, B., \& Ahmed AL-Dhamari, R. (2016). Firm Characteristics and Corporate Social Responsibility Disclosure. International Business Management, 10(18), 4283-4291.

Retrieved from http://docsdrive.com/pdfs/medwelljourna 1s/ibm/2016/4283-4291.pdf

Ali, W., \& Rizwan, M. (2013). Factors Influencing Corporate Social and Environmental Disclosure (CSED) Practices in The Developing Countries:
An Institutional Theoretical Perspective. International Journal of Asian Social Science, 3(3), 590-609. Retrieved from http://www.aessweb.com/pdf-files/590609.pdf

Alsaeed, K. (2006). The association between firm-specific characteristics and disclosure: The case of Saudi Arabia. Managerial Auditing Journal, 21(5), 476-496. https://doi.org/10.1108/02686900610667 256

Bagh, T., Khan, M. A., Azad, T., \& Atif Khan, M. (2017). The Corporate Social Responsibility and Firms' Financial Performance: Evidence from Financial Sector of Pakistan. International Journal of Economics and Financial Issues, 7(2), 301-308. Retrieved from http:www.econjournals.com

Bani-Khalid, T., Kouhy, R., \& Hassan, A. (2017). The Impact of Corporate Characteristics on Social and Environmental Disclosure (CSED): The Case of Jordan. Journal of Accounting and Auditing: Research \& Practice, 2017. https://doi.org/10.5171/2017.369352

Belal, A. R., \& Momin, M. (2009). Corporate Social Reporting (CSR) in emerging economies: a review and future direction. Research in Accounting in Emerging Economies, 9, 119-143. https://doi.org/10.1108/S14793563(2009)0000009007

Chapple, W., \& Moon, J. (2005). Corporate social responsibility (CSR) in Asia a seven-country study of CSR Web site reporting. Business and Society, 44(4), 415-441. https://doi.org/10.1177/00076503052816 58

Citraningrum, D. A., Handayani, S. R., \& Nuzula, N. F. (2014). Pengaruh Corporate Social Responsibility (CSR) Terhadap Financial Performance Dan Firm Value (Studi pada PerusahaanPerusahaan yang Terdaftar Pada Indeks SRI KEHATI Periode 2010-2012). Jurnal Administrasi Bisnis, 14(1), 1-10. 
Dasgupta, S., Laplante, B., \& Mamingi, N. (1998). Capital market responses to environmental performance in developing countries. In Policy Research Working Paper (No. 1909). https://doi.org/10.1016/j.jdeveco.2009.06 .005

Deegan, C. (2002). Introduction: The legitimising effect of social and environmental disclosures - a theoretical foundation. Accounting, Auditing \& Accountability Journal, 15(3), 282-311. https://doi.org/10.1108/09513570210435 852

Dias, A., Rodrigues, L. L., Craig, R., \& Neves, M. E. (2019). Corporate social responsibility disclosure in small and medium-sized entities and large companies. Social Responsibility Journal, 15(2), 137-154. https://doi.org/10.1108/SRJ-05-20170090

Djajadikerta, H. G., \& Trireksani, T. (2012). Corporate social and environmental disclosure by Indonesian listed companies on their corporate web sites. Journal of Applied Accounting Research, 13(1), 21-36. https://doi.org/10.1108/09675421211231 899

Dyduch, J., \& Krasodomska, J. (2017). Determinants of Corporate Social Responsibility Disclosure: An Empirical Study of Polish Listed Companies. Sustainability, 9, 1-24. https://doi.org/10.3390/su9111934

Fauzan, K., \& Kuswanto, D. A. (2018). The Effect of Capital Structure, GCG, CSR, Firm's Size on Market Value through Earnings Per Share in Banking Sector. Journal of Global Economics, 06(02). https://doi.org/10.4172/23754389.1000288

Fauziah, W., \& Adamu, M. (2016). The relationship between corporate social responsibility and financial performance: Evidence from Malaysia. International Business Management, 10(4), 345-351.

Fiori, G., Di Donato, F., \& Izzo, M. F. (2015). Corporate social responsibility and stock prices: A study on the italian market. Corporate Ownership and Control, 12(2 CONT5), 600-609.

Flammer, C. (2013). Corporate Social Responsibility and Shareholder Value: The Environmental Consciousness of Investors. Academy of Management Journal, 56(3), 758-781. https://doi.org/10.2139/ssrn.1888742

Gantyowati, E., \& Agustine, K. F. (2017). Firm's Characteristics and CSR Disclosure, Indonesia and Malaysia Cases. Review of Integrative Business and Economics Research Online CDROM, 6(3), 131-145.

Gunawan, J., Djajadikerta, H., \& Smith, M. (2009). An Examination of Corporate Social Disclosures in The Annual Reports of Indonesian Listed Companies. Asia Pacific Centre for Environmental Accountability Journal, 15(1), 13-36.

Herbohn, K., Walker, J., \& Loo, H. Y. M. (2014). Corporate Social Responsibility: The Link Between Sustainability Disclosure and Sustainability Performance. Abacus, 50(4), 422-459. https://doi.org/10.1111/abac.12036

Holder-Webb, L., Cohen, J. R., Nath, L., \& Wood, D. (2009). The supply of corporate social responsibility disclosures among U.S. firms. Journal of Business Ethics, 84(4), 497-527. https://doi.org/10.1007/s10551-0089721-4

Hooks, J., \& van Staden, C. J. (2011). Evaluating environmental disclosures: The relationship between quality and extent measures. British Accounting Review, 43(3), 200-213. https://doi.org/10.1016/j.bar.2011.06.005

Irham, A. R., Yuliana, S., \& Widiyanti, M. (2018). The effect firm characteristic on corporate social responsibility disclosure in the firms listed in Indonesia Sharia Stock Index. Jurnal Perspektif Pembiayaan Dan Pembangunan Daerah, 6(3), 303-318. https://doi.org/10.22437/ppd.v6i3.5820

Izzo, M. F., \& di Donato, F. (2012). The Relation between Corporate Social 
Responsibility and Stock Prices: An

Analysis of the Italian Listed Companies. SSRN Electronic Journal ·, (January). https://doi.org/10.2139/ssrn.1986324

Ji, Y., Xu, W., \& Zhao, Q. (2019). The real effects of stock prices: learning, disclosure and corporate social responsibility. Accounting \& Finance, (71771091), acfi.12494. https://doi.org/10.1111/acfi.12494

Juhmani, O. (2014). Determinants of Corporate Social and Environmental Disclosure on Websites : the Case of Bahrain. Universal Journal of Accounting and Finance 2(4):, 2(4), 7787. https://doi.org/10.13189/ujaf.2014.02040 2

Kamatra, N., \& Kartikaningdyah, E. (2015). Effect Corporate Social Responsibility on Financial Performance. International Journal of Economics and Financial Issues, 5, 157-164.

Kansal, M., Joshi, M., \& Batra, G. S. (2014). Determinants of corporate social responsibility disclosures: Evidence from India. Advances in Accounting, 30(1), 217-229. https://doi.org/10.1016/j.adiac.2014.03.0 09

Kaskeen, M. Y. M. (2017). Corporate Social Responsibility and Corporate Financial Performance: Case Study of Pakistan. Universal Journal of Management, 5(10), 457-476.

https://doi.org/10.13189/ujm.2017.05100 1

Khajavai, S., Taghizadeh, R., \& Maharluie, M. S. (2016). Corporate social responsibility and stock price crash risk: Evidence from an Asian emerging market. Iranian Journal of Accounting, Auditing \& Finance, 2(1), 95-114. https://doi.org/10.1108/MF-10-20150278

Kim, Y., Li, H., \& Li, S. (2014). Corporate social responsibility and stock price crash risk. Journal of Banking and Finance, 43(1), 1-13. https://doi.org/10.1016/j.jbankfin.2014.0
2.013

Klerk, M. De, Villiers, C. de, \& Staden, C. van. (2015). The influence of corporate social responsibility disclosure on share prices Evidence from the United Kingdom. Pacific Accounting Review, 27(2), 208-228. https://doi.org/http://dx.doi.org/10.1108/ MRR-09-2015-0216

Liu, X., \& Anbumozhi, V. (2009).

Determinant factors of corporate environmental information disclosure: an empirical study of Chinese listed companies. Journal of Cleaner Production, 17(6), 593-600. https://doi.org/10.1016/j.jclepro.2008.10. 001

Loderer, C., \& Waelchli, U. (2010). Protecting minority shareholders: Listed versus unlisted firms. Financial Management, 39(1), 33-57. https://doi.org/10.1111/j.1755053X.2009.01065.x

Lu, Y., \& Abeysekera, I. (2014). Stakeholders' power, corporate characteristics, and social and environmental disclosure: Evidence from China. Journal of Cleaner Production, 64, 426-436. https://doi.org/10.1016/j.jclepro.2013.10. 005

Lucyanda, J., \& Siagian, L. G. (2012). The influence of Corporate characteristics on Corporate Social Responsibility Disclosure. The 2012 International Conference on Business and Management, (September), 601-619.

Madugba, J., \& Okafor, M. (2016). Impact of Corporate Social Responsibility on Financial Performance: Evidence from Listed Banks in Nigeria. International Journal of Learning and Development, 4, 1-9. https://doi.org/10.5296/ijld.v2i6.2717

Müller, L., \& Wikström, M. (2016). Corporate Social Responsibility and its effect on stock price. Jönköping.

Narullia, D., Subekti, I., Azizah, N., \& Purnamasari, F. (2019). Value Relevance of Corporate Social Responsibility Disclosure on Public Companies in 
ASEAN Countries. KnE Social Sciences, 3(11), 475.

https://doi.org/10.18502/kss.v3i11.4027

Noordin, M. A., \& Mohtar, D. S. (2014). Age: Does it Matter for Firms to Perform? International Journal of Academic Research in Business and Social Sciences, 4(3), 252-260. https://doi.org/10.6007/IJARBSS/v4i3/704

Nurcahyanti, I., \& Widhianningrum, P. (2018). The Environmental Aspect of Companies as A Determinant of Stock Prices. Assets: Jurnal Akuntansi Dan Pendidikan, 7(2), 105.

https://doi.org/10.25273/jap.v7i2.2302

Oeyono, J., Samy, M., \& Bampton, R. (2011). Journal of Global Responsibility. Journal of Global Responsibility, 2(1), 100-112. Retrieved from http://dx.doi.org/10.1108/204125611111 28555\%0Ahttp://dx.doi.org/10.1108/174 71111111141549

Ortas, E., Álvarez, I., Zubeltzu, E., Ambe, C. M., Burritt, R., Ngwakwe, C. C., \& Lee, K.-H. (2017). Firms' Board Independence and Corporate Social Performance: A Meta-Analysis. https://doi.org/10.3390/su9061006

Pan, X., Sha, J., Zhang, H., \& Ke, W. (2014). Relationship between corporate social responsibility and financial performance in the mineral industry: Evidence from Chinese mineral firms. Sustainability (Switzerland), 6(7), 4077-4101. https://doi.org/10.3390/su6074077

Park, J. W., \& Lee, C. W. (2018). Performance of stock price with changes in SRI governance index. Corporate Social Responsibility and Environmental Management, 25(6), 1121-1129. https://doi.org/10.1002/csr.1526

Prasojo, \& Listyorini, I. (2015). The Influence of Corporate Social Responsibility toward the Financial Performance Company in Jakarta Islamic Index (JII) in Period 2010-2014. Global Review of Islamic Economics and Business, 3(2), 136-151.

Reverte, C. (2009). Determinants of corporate social responsibility disclosure ratings by Spanish listed firms. Journal of Business Ethics, 88(2), 351-366. https://doi.org/10.1007/s10551-0089968-9

Santhirasegar, J., Ramakrishnan, S., Hishan, S., \& Jamal, N. (2018). The Relationship Between Corporate Social Responsibility Practices and Firm Performance of Domestic Banks in Malaysia. International Journal of Engineering \& Technology, 7(2.29), 451.

https://doi.org/10.14419/ijet.v7i2.29.137 97

Sethi, S. P., Martell, T. F., \& Demir, M. (2017). An Evaluation of the Quality of Corporate Social Responsibility Reports by Some of the World's Largest Financial Institutions. Journal of Business Ethics, 140(4), 787-805. https://doi.org/10.1007/s10551-0152878-8

Shoukat Malik, M., \& Nadeem, M. (2014). Impact of Corporate Social Responsibility on the Financial Performance of Banks in Pakistan. International Letters of Social and Humanistic Sciences, 21, 9-19. https://doi.org/10.18052/www.scipress.co $\mathrm{m} / \mathrm{ilshs.21.9}$

Swandari, F., \& Sadikin, A. (2016). The Effect of Ownership Structure, Profitability, Leverage, and Firm Size on Corporate Social Responsibility (CSR). Binus Business Review, 7(3), 315. https://doi.org/10.21512/bbr.v7i3.1792

Utama, S. (2011). An evaluation of support infrastructures for corporate responsibility reporting in Indonesia. Asian Business and Management, 10(3), 405-424. https://doi.org/10.1057/abm.2011.10

Uzliawati, L., Rosiana, R., Samudi, M., Nawaiseh, M. E., Boa, S., Zaid, R. A., \& El-Shohnah, Y. (2015). Influence of Firm Size, Profitability and Size of Board of Commissioners on Corporate Social Responsibility Disclosures. Journal of Applied Finance \& Banking, 2(6), 97111. 
Waluyo, W. (2017). Firm size, firm age, and firm growth on corporate social responsibility in Indonesia: The case of real estate companies. European Research Studies Journal, 20(4), 360369.

Wang, M.-C. (2017). The Relationship between Firm Characteristics and the Disclosure of Sustainability Reporting. Sustainability, 9, 2-14. https://doi.org/10.3390/su9040624

Wang, Yu, H., \& Ahsan, T. (2016). The Impact of Environmental Information Disclosure on Business Performance : Evidence from High-Polluting Industries in China. European Journal of Business and Management, 8(18), 13-21.

Withisuphakorn, P., \& Jiraporn, P. (2016). The effect of firm maturity on corporate social responsibility (CSR): do older firms invest more in CSR? Applied Economics Letters, 23(4), 298-301. https://doi.org/10.1080/13504851.2015.1 071464
Wuttichindanon, S. (2017). Corporate social responsibility disclosure - choices of report and its determinants: Empirical evidence from firms listed on the Stock Exchange of Thailand. Kasetsart Journal of Social Sciences, 38(2), 156-162. https://doi.org/10.1016/j.kjss.2016.07.00 2

Xu, S., \& Liu, D. (2018). Do Financial Markets Care about Corporate Social Responsibility Disclosure? Further Evidence from China. Australian Accounting Review, 28(1), 79-103. https://doi.org/10.1111/auar.12161

Zaccheaus, S. A., Oluwagbemiga, O. E., \& Olugbenga, O. M. (2014). Effects of corporate social responsibility performance ( CSR ) on stock prices : Empirical study of listed manufacturing companies Solomon Adeoluwa Zaccheaus, 2 Oyerogba Ezekiel Oluwagbemiga, Olaleye Michael Olugbenga. IOSR Journal of Business and Management, 16(8), 112-117. 